\title{
Cardiovascular diseases in Chinese, Malays, and Indians in Singapore. I. Differences in mortality
}

\author{
Kenneth Hughes, K C Lun, Peter P B Yeo
}

\begin{abstract}
Study objective-The aim of the study was to analyse differences in mortality from the main cardiovascular diseases (ischaemic heart disease, hypertensive disease, and cerebrovascular disease) among Chinese, Malays, and Indians in Singapore.

Design-The study was a survey using national death registration data in Singapore for the five years 1980 to 1984 . The underlying cause of death, coded according to the ninth revision of the International Classification of Diseases, was taken for the analyses.
\end{abstract}

Setting-The study was confined to the independent island state of Singapore, population 2.53 million (Chinese $76.5 \%$, Malays $14 \cdot 8 \%$, Indians $6 \cdot 4 \%$, Others $2 \cdot 3 \%$ ). Death registration is thought to be complete.

Subjects-All registered deaths in the age range 30-69 years during the study period were analysed by ethnic group.

Measurement and main results-Indians had higher mortality from ischaemic heart disease than the other ethnic groups in both sexes, with age-standardised relative risks of Indian $v$ Chinese (males 3.8, females 3.4), Indian $v$ Malay (males 1.9, females 1.6), and Malay $v$ Chinese (males $2 \cdot 0$, females $2 \cdot 2$ ). The excess mortality in Indians declined with age. For hypertensive disease Malays had the highest mortality, with agestandardised relative risks of Malay $v$ Chinese (males 3.4, females 4.4), Malay $v$ Indian (males $2 \cdot 0$, females $2 \cdot 5$ ), and Indian $v$ Chinese (males 1.6, females 1.6). For cerebrovascular disease there was little ethnic difference except for lower rates in Chinese females, with age-standardised relative risks of Malay $v$ Chinese (males 1.1, females 1.9), Malay $v$ Indian (males $1 \cdot 0$, females $1 \cdot 1$ ), and Indian $v$ Chinese (males $1 \cdot 1$, females $1 \cdot 7$ ).

Conclusions-There are significant differences in mortality from the three main cardiovascular diseases in the different ethnic groups in Singapore.

The comparison of disease frequency in different ethnic groups helps to unravel the contributions of nature and nurture in their aetiology and to identify environmental factors that may be involved. This is provided of course that the diagnostic accuracy and completeness are comparable, which are aided when the groups are considered in the same country.
Studies have shown that for many noncommunicable diseases migrant groups have rates generally intermediate between those of the country of origin and country of adoption. ${ }^{1}$ This phenomenon indicates the importance of environmental factors and can be explained by the fact that migrants, while taking up the physical and to some extent the social environment of the adopted country, still retain some behavioural characteristics of their country of origin (such as diet). For ischaemic heart disease this is exemplified in a study of migrants to England and Wales. ${ }^{2}$ In Indian migrants however (ie, those from the Indian subcontinent) the frequency of ischaemic heart disease seems to exceed not only that of the country of origin but also that of the adopted country. Indians have been shown to have a greater susceptibility to the disease than other ethnic groups in Africa, ${ }^{34}$ the West Indies, ${ }^{5}$ and England. ${ }^{7}$ Comparison with the country of origin is less clear as in India itself there have been few epidemiological studies on ischaemic heart disease, though low frequencies have been shown from an analysis of death certificates of Indian railwaymen ${ }^{8}$ and in a further study in Northern India. ${ }^{9}$ It has been stated that further research is required into ischaemic heart disease in Indians. ${ }^{10}$

Singapore is an independent island state of 620 $\mathrm{km}^{2}$ which in June 1984 had a population of 2.53 million people, composed of Chinese $(76.5 \%$ ), Malays $(14.8 \%)$, Indians $(6.4 \%)$, and Others $(2.3 \%) .{ }^{11}$ The Chinese, Malays and Indians are descendants of immigrants who have come to Singapore since the early 19 th century from the southern provinces of China, the Malaysian peninsula and Indonesia, and the Indian subcontinent, respectively. The majority of Indians (approximately $80 \%$ ) have their origins in the southern Indian states (Tamil Nadu and Kerala) and Sri Lanka (largely the Tamils). These ethnic groups live in the same environment (though retaining some of their customs, particularly diet) and there is easy access to medical care both because of the small size of the island and the availability of a subsidised government health service as well as private health care.

Singaporeans now have a high standard of living, the two commonest causes of death being cardiovascular diseases and cancers. ${ }^{11}$ An analysis of trends from 1959 to 1983 found that death rates from ischaemic heart disease have increased steadily over the period, though recently they have declined in the younger ages with a birth cohort effect. ${ }^{12}$ Likewise mortality from cerebrovascular disease, after an initial slight rise, has shown a modest decline starting in the early to mid-1970s, while hypertensive disease mortality, 
again after an initial rise, fell markedly from the mid-1960s. ${ }^{13}$ This study compares mortality from these three cardiovascular diseases among the three main ethnic groups for the years 1980 to 1984 combined, in the ages 30 to 69 years.

\section{Methods}

Death registration information for the five years from 1980 to 1984 was obtained on computer tape from the Department of Statistics, to which all vital events in Singapore are reported. The international death certificate is used and the underlying cause of death, coded according to the ninth revision of International Classification of Diseases of the World Health Organization (1975), has been taken for the analyses. In Singapore all people are designated by ethnic group, and this information is on their identity cards. Offspring follow the ethnic group of the father but there has in the past been little intermarriage between Chinese, Malays and Indians. It should be noted that Eurasians (largely the descendants of early European settlers) are a distinct small group in Singapore and included under Others, and hence excluded from this study. To calculate annual age specific death rates the average annual mortality over the five years (1980-84) was divided by the mid-point population (ie, mid-1982), which is estimated from the mid-1980 census allowing for births and deaths. ${ }^{11}$

In looking at mortality statistics it is necessary to consider the data with regard to completeness and accuracy. Death and birth registration in Singapore is considered virtually complete as they are legal requirements; death has to be reported before a burial or cremation permit is issued and a birth certificate is needed for a number of administrative purposes. In the five years there was just one death with no diagnosis recorded and the proportion of death certificates with age not stated was very low, being $0.29 \%$ in males and $0.05 \%$ in females where the diagnosis was one of the three cardiovascular diseases.

Concerning accuracy of diagnosis the percentage of deaths for ages 30 to 69 years due to "symptoms and ill defined conditions" (ICD 780-799) was low, being for males, Chinese 0.4\%, Malays $1.5 \%$, Indians $0.2 \%$ and for females, Chinese $0.5 \%$, Malays $1.5 \%$, and Indians $0.4 \%$. Likewise within cardiovascular diseases the percentage of deaths in persons $30-69$ years due to "other and unspecified diseases of circulatory system (441-459)" was low, being $1.9 \%$ for males and $1.0 \%$ for females. Over the period 1980 to 1984 certification of death was done by medical officers and practitioners $(68 \cdot 1 \%)$, coroners $(21.9 \%)$, inspectors of the dead $(9.9 \%)$, and police officers $(0.1 \%)$. Hence $90.0 \%$ of deaths had the cause certified by medically qualified personnel. The proportion certified by police officers is insignificant and largely involves violence. Inspectors of the dead are fully registered nurses with thorough death certification training. They see mainly elderly persons (over 70 years) and those recently discharged from hospital; they make a full enquiry of the case and if there appears any doubt refer the case to the coroner. Also the period of study covers only five years and so changing diagnostic fashion, criteria, and techniques are not involved. There is no problem with linkage of numerator and denominator as both are national.

For the analysis the data were processed using the SAS statistical package. The age standardised relative risks are ratios where both numerator and denominator rates have been standardised for ages 30 to 69 years by the direct method to the total mid-1982 (male and female) Singapore population using five year age groups, and hence are comparable amongst the three ethnic groups and both sexes. It should be noted that there is no significance testing because these are complete national data rather than samples and hence there is no sampling error.

\section{Results}

Mortality rates are shown in table I for males and in table II for females. Over the period the proportionate mortality rates in ages 30 to 69 years for ischaemic heart disease in males were $16.5 \%$ in Chinese, $32.1 \%$ in Malays and $45.3 \%$ in Indians; for cerebrovascular disease $9.1 \%$ in Chinese, $10.1 \%$ in Malays, and $7.4 \%$ in Indians; and for hypertensive disease $1.6 \%$ in Chinese, $5.2 \%$ in Malays and $1.8 \%$ in Indians. For all three cardiovascular disease combined the proportionate mortality rates in males were $27.2 \%$ in Chinese, $47.4 \%$ in Malays and $54.5 \%$ in Indians. In females the proportionate mortality rates for ischaemic heart disease were $13.1 \%$ in Chinese, $17.4 \%$ in Malays and $24.7 \%$ in Indians; for cerebrovascular disease $13.2 \%, 15.2 \%$, and $11.6 \%$ respectively; and for hypertensive disease $2.4 \%, 6.5 \%$ and $2.3 \%$. For all three cardiovascular diseases combined the proportionate mortality rates in females were $28 \cdot 7 \%$ in Chinese, $39.0 \%$ in Malays and $38.6 \%$ in Indians. Taking into account the limitations of proportional rates there is the suggestion that ischaemic heart disease is more common in Indians and hypertensive disease in Malays, with little ethnic difference in cerebrovascular disease.

The proportion of ischaemic heart disease which is due to acute myocardial infarction is much the same among the sexes and ethnic groups. These are for males, $83.7 \%$ in Chinese, $84.6 \%$ in Malays, and $83.4 \%$ in Indians; for females they are respectively $82.7 \%, 81.3 \%$, and $80.4 \%$. These data provide some evidence that there are no diagnostic differences or biases across ethnic groups.

The pattern of mortality in males for ischaemic heart disease is consistent in all age groups, being highest in Indians, followed by Malays, and then Chinese (tables I and III). For Malays the excess mortality over Chinese changes little over the age groups (excluding the 30-39 age group which has relatively small numbers of deaths). However excess mortality in Indians over Chinese and Malays declines steadily with age so that the Indian to Chinese relative risk is 12.5 in the $30-39$ age group, 5.0 in the $40-49$ age group, 3.9 in the $50-59$ age group, and 3.0 in the $60-69$ age group; likewise against Malays the relative risks are $4 \cdot 4$, $2.7,1.9$ and 1.6 respectively (table III). Overall Indians are seen to have markedly higher death rates from ischaemic heart disease than Chinese 


\begin{tabular}{|c|c|c|c|c|c|c|c|c|}
\hline \multirow[b]{2}{*}{$\begin{array}{l}\text { Age } \\
\text { group } \\
\text { (years) }\end{array}$} & \multirow[b]{2}{*}{$\begin{array}{l}\text { Ethnic } \\
\text { group }\end{array}$} & \multirow[b]{2}{*}{$\begin{array}{l}\text { Population } \\
\text { (thousands) }\end{array}$} & \multicolumn{6}{|c|}{ Cause of death (ICD code) } \\
\hline & & & All causes & $\begin{array}{l}\text { Acute } \\
\text { myocardial } \\
\text { infarction } \\
(410)\end{array}$ & $\begin{array}{l}\text { Other } \\
\text { ischaemic } \\
\text { heart } \\
\text { disease } \\
(411-414)\end{array}$ & $\begin{array}{l}\text { Ischaemic } \\
\text { heart } \\
\text { disease } \\
(410-414)\end{array}$ & $\begin{array}{l}\text { Cerebro- } \\
\text { vascular } \\
\text { disease } \\
(430-438)\end{array}$ & $\begin{array}{l}\text { Hypertensive } \\
\text { disease } \\
(401-405)\end{array}$ \\
\hline 30-39 & $\begin{array}{l}\text { Chinese } \\
\text { Malay } \\
\text { Indian }\end{array}$ & $\begin{array}{r}153.1 \\
23.7 \\
11.8\end{array}$ & $\begin{array}{l}141 \cdot 7(1085) \\
178.9(212) \\
327 \cdot 1 \quad(193)\end{array}$ & $\begin{aligned} 5.4 & (41) \\
16.9 & (20) \\
79.7 & (47)\end{aligned}$ & $\begin{array}{ll}1.4 & (11) \\
2.5 & (3) \\
5.1 & (3)\end{array}$ & $\begin{array}{rr}6.8 & (52) \\
19.4 & (23) \\
84.7 & (50)\end{array}$ & $\begin{array}{lr}5.9 & (45) \\
5.1 & (6) \\
8.5 & (5)\end{array}$ & $\begin{array}{rr}1.4 & (11) \\
1.7 & (2) \\
5.1 & (3)\end{array}$ \\
\hline $40-49$ & $\begin{array}{l}\text { Chinese } \\
\text { Malay } \\
\text { Indian }\end{array}$ & $\begin{array}{r}99 \cdot 0 \\
15 \cdot 3 \\
9 \cdot 3\end{array}$ & $\begin{array}{l}398.2(1971) \\
397.4(304) \\
733.3 \quad(341)\end{array}$ & $\begin{array}{r}58.0(287) \\
105.9(81) \\
273.1(127)\end{array}$ & $\begin{aligned} 9 \cdot 1 & (45) \\
18 \cdot 3 & (14) \\
60 \cdot 2 & (28)\end{aligned}$ & $\begin{array}{rr}67 \cdot 1 & (332) \\
124 \cdot 2 & (95) \\
333 \cdot 3 & (155)\end{array}$ & $\begin{array}{l}31.9(158) \\
22.2(17) \\
28.0(13)\end{array}$ & $\begin{array}{rr}5 \cdot 7 & (28) \\
20.9 & (16) \\
4.3 & (2)\end{array}$ \\
\hline $50-59$ & $\begin{array}{l}\text { Chinese } \\
\text { Malay } \\
\text { Indian }\end{array}$ & $\begin{array}{l}62.6 \\
13 \cdot 4 \\
11 \cdot 7\end{array}$ & $\begin{array}{l}1253.7(3924) \\
1261.2(845) \\
1738.5(1017)\end{array}$ & $\begin{array}{l}192.0(601) \\
411.9(276) \\
770.9(451)\end{array}$ & $\begin{array}{r}39.3(123) \\
62.7(42) \\
141.9(83)\end{array}$ & $\begin{array}{ll}231 \cdot 3 & (724) \\
474 \cdot 6 & (318) \\
912 \cdot 8 & (534)\end{array}$ & $\begin{array}{l}113.4(355) \\
144.8(97) \\
104.3(61)\end{array}$ & $\begin{array}{ll}21.1 & (66) \\
53.7 & (36) \\
27.4 & (16)\end{array}$ \\
\hline $60-69$ & $\begin{array}{l}\text { Chinese } \\
\text { Malay } \\
\text { Indian }\end{array}$ & $\begin{array}{r}40 \cdot 6 \\
7 \cdot 2 \\
6 \cdot 1\end{array}$ & $\begin{array}{l}3302 \cdot 5(6704) \\
3286 \cdot 1(1183) \\
3954 \cdot 1(1206)\end{array}$ & $\begin{array}{r}470.9(956) \\
872.2(314) \\
1363.9(416)\end{array}$ & 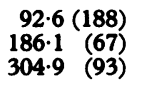 & $\begin{array}{r}563.5(1144) \\
1058.3(381) \\
1668.9(509)\end{array}$ & $\begin{array}{l}340.9(692) \\
377.8(136) \\
409.8(125)\end{array}$ & $\begin{array}{r}58.1(118) \\
216.7(78) \\
98.4(30)\end{array}$ \\
\hline
\end{tabular}

Table I Age specific annual death rates per 100000 from cardiovascular diseases, males, 1980-1984. Data are rates (numbers of deaths)

\begin{tabular}{|c|c|c|c|c|c|c|c|c|}
\hline \multirow[b]{2}{*}{$\begin{array}{l}\text { Age } \\
\text { group } \\
\text { (years) }\end{array}$} & \multirow[b]{2}{*}{$\begin{array}{l}\text { Ethnic } \\
\text { group }\end{array}$} & \multirow[b]{2}{*}{$\begin{array}{l}\text { Population } \\
\text { (thousands) }\end{array}$} & \multicolumn{6}{|c|}{ Cause of death (ICD code) } \\
\hline & & & All causes & $\begin{array}{l}\text { Acute } \\
\text { myocardial } \\
\text { infarction } \\
(410)\end{array}$ & $\begin{array}{l}\text { Other } \\
\text { ischaemic } \\
\text { heart } \\
\text { disease } \\
(411-414)\end{array}$ & $\begin{array}{l}\text { Ischaemic } \\
\text { heart } \\
\text { disease } \\
(410-414)\end{array}$ & $\begin{array}{l}\text { Cerebro- } \\
\text { vascular } \\
\text { disease } \\
(430-438)\end{array}$ & $\begin{array}{l}\text { Hypertensive } \\
\text { disease } \\
(401-405)\end{array}$ \\
\hline $30-39$ & $\begin{array}{l}\text { Chinese } \\
\text { Malay } \\
\text { Indian }\end{array}$ & $\begin{array}{r}149 \cdot 0 \\
23.5 \\
10.4\end{array}$ & $\begin{array}{rr}92.8 & (691) \\
111.5 & (131) \\
128.8 & (67)\end{array}$ & $\begin{array}{lr}1.6 & (12) \\
0.9 & (1) \\
9.6 & (5)\end{array}$ & $\begin{array}{ll}0.1 & (1) \\
0.9 & (1) \\
1.9 & (1)\end{array}$ & $\begin{array}{rr}1.7 & (13) \\
1.7 & (2) \\
11.5 & (6)\end{array}$ & $\begin{array}{lr}3 \cdot 8 & (28) \\
4 \cdot 3 & (5) \\
7 \cdot 7 & (4)\end{array}$ & $\begin{array}{ll}0.7 & (5) \\
6.0 & (7) \\
5.8 & (3)\end{array}$ \\
\hline $40-49$ & $\begin{array}{l}\text { Chinese } \\
\text { Malay } \\
\text { Indian }\end{array}$ & $\begin{array}{r}98 \cdot 2 \\
16 \cdot 7 \\
7 \cdot 4\end{array}$ & $\begin{array}{ll}228.7 & (1123) \\
319.8 \quad(267) \\
359.5 & (133)\end{array}$ & $\begin{array}{ll}12.0 & (59) \\
37 \cdot 1 & (31) \\
62 \cdot 2 & (23)\end{array}$ & $\begin{array}{rr}2 \cdot 2 & (11) \\
6.0 & (5) \\
10.8 & (4)\end{array}$ & $\begin{array}{ll}14 \cdot 3 & (70) \\
43 \cdot 1 & (36) \\
73 \cdot 0 & (27)\end{array}$ & $\begin{array}{l}23 \cdot 8(117) \\
44 \cdot 3(37) \\
24 \cdot 3 \quad(9)\end{array}$ & $\begin{array}{rr}5 \cdot 3 & (26) \\
15 \cdot 6 & (13) \\
8 \cdot 1 & (3)\end{array}$ \\
\hline $50-59$ & $\begin{array}{l}\text { Chinese } \\
\text { Malay } \\
\text { Indian }\end{array}$ & $\begin{array}{r}67 \cdot 1 \\
11 \cdot 4 \\
4 \cdot 5\end{array}$ & $\begin{array}{r}635.5(2132) \\
1059.6 \quad(604) \\
1022.2 \quad(230)\end{array}$ & $\begin{array}{r}64 \cdot 4 \\
170 \cdot 2(216) \\
200 \cdot 0(47)\end{array}$ & $\begin{array}{ll}11.6 & (39) \\
31.6 & (18) \\
62.2 & (14)\end{array}$ & $\begin{array}{r}76.0(255) \\
201.8(115) \\
262.2(59)\end{array}$ & $\begin{array}{r}80 \cdot 8(271) \\
177 \cdot 2(101) \\
102 \cdot 2(23)\end{array}$ & $\begin{array}{cc}12 \cdot 2 & (41) \\
68 \cdot 4 & (39) \\
26 \cdot 7 & (6)\end{array}$ \\
\hline $60-69$ & $\begin{array}{l}\text { Chinese } \\
\text { Malay } \\
\text { Indian }\end{array}$ & $\begin{array}{r}48.6 \\
5.4 \\
1.9\end{array}$ & $\begin{array}{l}1753.5(4261) \\
2766.7 \quad(747) \\
3115.8 \quad(296)\end{array}$ & $\begin{array}{l}246.9(600) \\
437.0(118) \\
747.4(71)\end{array}$ & $\begin{array}{r}55 \cdot 1(134) \\
122 \cdot 2(33) \\
168 \cdot 4(16)\end{array}$ & $\begin{array}{l}302 \cdot 1(734) \\
559 \cdot 3(151) \\
915.8(87)\end{array}$ & $\begin{array}{l}275.7(670) \\
451.9(122) \\
505.3(48)\end{array}$ & $\begin{array}{rr}50 \cdot 2 & (122) \\
200 \cdot 0 & (54) \\
52.6 & (5)\end{array}$ \\
\hline
\end{tabular}

Table II Age specific annual death rates per 100000 from cardiovascular diseases, females, 1980-1984. Data are rates (numbers of deaths)

Table III Ethnic group relative risks for mortality from cardiovascular diseases by sex and age group, 1980-1984

\begin{tabular}{|c|c|c|c|c|c|c|c|}
\hline \multirow{3}{*}{$\begin{array}{l}\text { Age } \\
\text { group } \\
\text { years }\end{array}$} & \multirow{3}{*}{ Ethnic group } & \multicolumn{6}{|c|}{ Cause of death (ICD code) } \\
\hline & & \multicolumn{2}{|c|}{$\begin{array}{l}\text { Ischaemic heart disease } \\
(410-414)\end{array}$} & \multicolumn{2}{|c|}{$\begin{array}{l}\text { Cerebrovascular disease } \\
(430-438)\end{array}$} & \multicolumn{2}{|c|}{$\begin{array}{l}\text { Hypertensive disease } \\
(401-405)\end{array}$} \\
\hline & & Males & Females & Males & Females & Males & Females \\
\hline $30-39$ & $\begin{array}{l}\text { Malay/Chinese } \\
\text { Indian/Chinese } \\
\text { Indian/Malay }\end{array}$ & $\begin{array}{r}2.9 \\
12.5 \\
4.4\end{array}$ & $\begin{array}{l}1.0 \\
6.8 \\
6.8\end{array}$ & $\begin{array}{l}0.9 \\
1.4 \\
1.7\end{array}$ & $\begin{array}{l}1 \cdot 1 \\
2.0 \\
1.8\end{array}$ & $\begin{array}{l}1 \cdot 2 \\
3 \cdot 6 \\
3 \cdot 0\end{array}$ & $\begin{array}{l}8 \cdot 6 \\
8 \cdot 3 \\
1 \cdot 0\end{array}$ \\
\hline $40-49$ & $\begin{array}{l}\text { Malay/Chinese } \\
\text { Indian/Chinese } \\
\text { Indian/Malay }\end{array}$ & $\begin{array}{l}1.9 \\
5.0 \\
2.7\end{array}$ & $\begin{array}{l}3.0 \\
5.1 \\
1.7\end{array}$ & $\begin{array}{l}0.7 \\
0.9 \\
1.3\end{array}$ & $\begin{array}{l}1.9 \\
1.0 \\
0.5\end{array}$ & $\begin{array}{l}3.7 \\
0.8 \\
0.2\end{array}$ & $\begin{array}{l}2.9 \\
1.5 \\
0.5\end{array}$ \\
\hline $50-59$ & $\begin{array}{l}\text { Malay/Chinese } \\
\text { Indian/Chinese } \\
\text { Indian/Malay }\end{array}$ & $\begin{array}{l}2.1 \\
3.9 \\
1.9\end{array}$ & $\begin{array}{l}2.7 \\
3.5 \\
1.3\end{array}$ & $\begin{array}{l}1.3 \\
0.9 \\
0.7\end{array}$ & $\begin{array}{l}2.2 \\
1.3 \\
0.6\end{array}$ & $\begin{array}{l}2.5 \\
1.3 \\
0.5\end{array}$ & $\begin{array}{l}5 \cdot 6 \\
2 \cdot 2 \\
0 \cdot 4\end{array}$ \\
\hline $60-69$ & $\begin{array}{l}\text { Malay/Chinese } \\
\text { Indian/Chinese } \\
\text { Indian/Malay }\end{array}$ & $\begin{array}{l}1.9 \\
3.0 \\
1.6\end{array}$ & $\begin{array}{l}1.9 \\
3.0 \\
1.6\end{array}$ & $\begin{array}{l}1 \cdot 1 \\
1 \cdot 2 \\
1 \cdot 1\end{array}$ & $\begin{array}{l}1 \cdot 6 \\
1 \cdot 8 \\
1 \cdot 1\end{array}$ & $\begin{array}{l}3.7 \\
1.7 \\
0.5\end{array}$ & $\begin{array}{l}4 \cdot 0 \\
1 \cdot 0 \\
0 \cdot 3\end{array}$ \\
\hline $30-69 \star$ & $\begin{array}{l}\text { Malay/Chinese } \\
\text { Indian/Chinese } \\
\text { Indian/Malay }\end{array}$ & $\begin{array}{l}2.0 \\
3.8 \\
1.9\end{array}$ & $\begin{array}{l}2 \cdot 2 \\
3 \cdot 4 \\
1 \cdot 6\end{array}$ & $\begin{array}{l}1.1 \\
1.1 \\
1.0\end{array}$ & $\begin{array}{l}1.9 \\
1.7 \\
0.9\end{array}$ & $\begin{array}{l}3.4 \\
1.6 \\
0.5\end{array}$ & $\begin{array}{l}4 \cdot 4 \\
1 \cdot 6 \\
0 \cdot 4\end{array}$ \\
\hline
\end{tabular}

* Age standardised to the 1982 total population

and Malays (age standardised relative risks of 3.8 and 1.9 respectively) while Malays have twice the adjusted rates of Chinese.

For females table III shows that for ischaemic heart disease the pattern by ethnic group is rather similar; Indians again have much higher rates than the other groups, with the Indian $v$ Chinese relative risk falling with age. Indeed except for the 30-39 age group (where the number of deaths are small) the relative risks are very similar to those for males. Malays again have a slight excess over
Chinese, though this does fall slightly with age (again excluding the 30-39 age group). Table IV shows that for ischaemic heart disease the male/ female relative risks decline steadily with age and are much the same by ethnic group.

For cerebrovascular disease, the ethnic differences in mortality are much less, with no consistent trend by age group (tables I, II, and III). The rates are much the same for Malays and Indians, but Chinese have somewhat lower rates, especially in females; table III shows the age 
Table IV Male to female relative risks for mortality from cardiovascular diseases by age group, 1980-1984

\begin{tabular}{|c|c|c|c|c|c|c|c|c|c|}
\hline \multirow{3}{*}{$\begin{array}{l}\text { Age } \\
\text { group } \\
\text { (years) }\end{array}$} & \multicolumn{9}{|c|}{ Cause of death (ICD code) } \\
\hline & \multicolumn{3}{|c|}{$\begin{array}{l}\text { Ischaemic heart disease } \\
(410-414)\end{array}$} & \multicolumn{3}{|c|}{$\begin{array}{l}\text { Cerebrovascular disease } \\
(430-438)\end{array}$} & \multicolumn{3}{|c|}{$\begin{array}{l}\text { Hypertensive disease } \\
(401-405)\end{array}$} \\
\hline & Chinese & Malay & Indian & Chinese & Malay & Indian & Chinese & Malay & Indian \\
\hline $\begin{array}{l}30-39 \\
40-49 \\
50-59 \\
60-69 \\
30-69 \star\end{array}$ & $\begin{array}{l}4 \cdot 0 \\
4 \cdot 7 \\
3 \cdot 0 \\
1 \cdot 9 \\
2 \cdot 4\end{array}$ & $\begin{array}{r}11.4 \\
2.9 \\
2.4 \\
1.9 \\
2.2\end{array}$ & $\begin{array}{l}7.4 \\
4.6 \\
3.5 \\
1.8 \\
2.7\end{array}$ & $\begin{array}{l}1.6 \\
1.3 \\
1.4 \\
1.2 \\
1.3\end{array}$ & $\begin{array}{l}1.2 \\
0.5 \\
0.8 \\
0.8 \\
0.8\end{array}$ & $\begin{array}{l}1 \cdot 1 \\
1 \cdot 2 \\
1 \cdot 0 \\
0.8 \\
0.9\end{array}$ & $\begin{array}{l}2 \cdot 0 \\
1.1 \\
1.7 \\
1.2 \\
1.3\end{array}$ & $\begin{array}{l}0.3 \\
1.3 \\
0.8 \\
1.1 \\
1.0\end{array}$ & $\begin{array}{l}0.9 \\
0.5 \\
1.0 \\
1.9 \\
1.3\end{array}$ \\
\hline
\end{tabular}

* Age standardised to the 1982 total population

standardised relative risks are Malay $v$ Chinese (males $1 \cdot 1$, females 1.9 ) and Indian $v$ Chinese (males 1.1, females 1.7). Table IV shows that for cerebrovascular disease there is little sex difference for Malays and Indians though overall females seem to have slightly higher rates, especially in Malays; however for Chinese there is a definite male excess in all age groups, with lower rates in Chinese females.

Tables I, II and III also show that for both sexes Malays have the highest death rates from hypertensive disease, with Indians slightly more than Chinese; the age standardised relative risks are Malay $v$ Chinese (males 3.4, females 4.4 ) and Malay $v$ Indian (males $2 \cdot 0$, females $2 \cdot 5$ ). The rates are about the same in the two sexes for Malays, with Chinese and Indians having slightly higher rates in males than females (table IV).

\section{Discussion}

This study, which is based on complete national death registration data, has shown a higher mortality from ischaemic heart disease in Indians compared with Chinese and Malays. This confirms the increased frequency of the disease in Indians described in other parts of the world, ${ }^{3-7}$ as well as in Singapore from autopsy records. ${ }^{14}$ In Trinidad $^{5}$ and England ${ }^{7}$ the Indians are mostly from north India, though in the latter study diseases of the circulatory system were highest in the small group from south India compared with other Indian groups, although not at a significant level. ${ }^{7}$ In Singapore the majority of the Indians (about $80 \%$ ) have their origins in south India and Sri Lanka. From an analysis of death certificates of Indian railwaymen it was reported that while mortality from ischaemic heart disease was low, southern Indians had a higher frequency of the disease than northern Indians, though the selective nature of this study should be borne in mind. ${ }^{8}$

In this study in Singapore the excess mortality from ischaemic heart disease in Indians compared to Chinese and Malays is present in both sexes, though slightly more in males than females, and falls steadily with age. Hence whatever is responsible for the increased susceptibility of Indians to the disease, it is present in both sexes and has lessening effect with age. Malays have higher mortality from ischaemic heart disease than Chinese and here again the excess mortality is found in both sexes, but unlike the finding in Indians, the excess in Malays does not decline with age, which suggests that different factors may be operating. This study has also shown that in all three ethnic groups the higher risk of males over females for ischaemic heart disease steadily declines with age and does not just occur abruptly at the menopause.

It has also been found that Malays have higher mortality rates from hypertensive disease than Chinese and Indians in both sexes, but for cerebrovascular disease the excess is much less. As hypertension is the main risk factor for both of these conditions the reason for this is not clear and needs further investigation. It has been reported from clinical observation in neighbouring Malaysia that Malays (particularly females) have an apparent susceptibility to hypertension. ${ }^{15}$

The higher mortality from cerebrovascular disease in Indian males reported in England and Wales ${ }^{7}$ has not been found in Singapore; for males the rates are very similar overall in the three ethnic groups though in females, Chinese have somewhat lower rates than Malays and Indians. It has also been reported from autopsy studies in Singapore that the only difference between Indians and Chinese for cardiovascular disease was in coronary disease. ${ }^{14}$ It therefore seems that the increased susceptibility of Indians to arterial disease involves the coronary but not the cerebral arteries, which suggests that higher blood pressures are not a major contributory factor. This finding is in keeping with the hypothesis that different risk factors are involved in the pathogenesis of ischaemic heart disease and cerebrovascular disease. ${ }^{16}$ The sex differences for cerebrovascular disease found in Singapore are small and consistent with the findings of others. ${ }^{17}$ The possible exception to this is in Chinese, but the lower rates for all three cardiovascular diseases in Chinese females are noteworthy and are reflected in their much lower overall mortality (tables I and II).

This study has therefore shown interesting differences in mortality from the three cardiovascular diseases in the three ethnic groups. A cross sectional survey has been carried out in Singapore to compare levels of cardiovascular risk factors in the three ethnic groups to see how far these can explain the differences in mortality and is reported in the accompanying paper. ${ }^{18}$

We thank the Department of Statistics, Singapore Government for supplying us with the computer tape of death registration data. This study formed part of the dissertation (The Epidemiology of Cardiovascular Diseases in the Ethnic Groups of Singapore) by KH, for the degree of Doctor of Medicine, University of Oxford, 1989.

1 Reid DD. International studies in epidemiology. Am $\mathcal{f}$ Epidemiol 1975; 102: 469-76.

2 Marmot MG, Adelstein AM, Bulusu L. Lessons from the study of immigrant mortality. Lancet 1984; i: 1455-8. 
3 Shaper AG, Jones KW. Serum cholesterol, diet, and coronary heart disease in Africans and Asians in Uganda. Coronary heart disease
Lancet 1959 ; ii: $534-7$.

4 Walker ARP. The epidemiology of ischaemic heart disease in the different ethnic populations in Johannesburg. $S A f$

5 Miller GJ, Beckles GLA, Alexis SD, Byam NTA, Price SGL. Serum lipoproteins and susceptibility of men of Indian descent to coronary heart disease. The St. James survey, Trinidad. Lancet 1982; ii: 200-3.

6 Tunstall-Pedoe H, Clayton D, Morris JN, Brigden W. McDonald $L$. Coronary heart attacks in east London. Lancet 1975; ii: 833-8.

7 Balarajan R, Bulusu L, Adelstein AM, Shukla V. Patterns of mortality among migrants to England and Wales from the Indian sub-continent. $\mathrm{Br}$ Med $\mathscr{F}$ 1984; 289: 1185-7.

8 Malhotra SL. Epidemiology of ischaemic heart disease in an Indian population with special reference to causation. $\mathrm{Br}$ Indian population with special

9 Sarvotham SG, Berry JN. Prevalence of coronary heart disease in an urban population in Northern India. disease in an urban populat
Circulation 1968; 37: 939-53.

10 Editorial. Coronary heart disease in Indians overseas. Lancet 1986; ii: $1307-8$.
11 Registrar-General of Births and Deaths. Report on registration of births and deaths various years. Republic of registration

12 Hughes $\mathrm{K}$. Trends in mortality from ischaemic heart disease in Sin $K$. Trends in mortality from ischaemic heart disease in Singapore, 1959 to 1983 . Int $f$ Epidemiol $1986 ; 15: 44-50$. 3 Hughes $\mathrm{K}$. Trends in mortality from hypertensive and cerebrovascular diseases in

14 Danaraj TJ, Acker MS, Danaraj W, Wong HO, Tan BY. Ethnic group differences in coronary heart disease in Singapore: an analysis of necropsy records. Am Heart $\mathcal{f}$ 1959; 58: 516-26.

15 Volp U. Hypertension, a health problem in Malaysia? Bull Public Health Soc Malaysia 1975; 9: 59-65.

16 Editorial. Cerebral infarction and myocardial infarction: a similar aetiology? Lancet 1978; i: 1239-40.

17 Tunstall-Pedoe H. Stroke. In: Miller DL, Farmer RDT, eds. Epidemiology of diseases. Oxford: Blackwell Scientific Publications, 1982: 136-45.

18 Hughes K, Yeo PPB, Lun KC, et al. Cardiovascular diseases in Chinese, Malays, and Indians in Singapore. II. in Chinese, Malays, and Indians in Singapore. II. Health 1990; 44: 29-35. 